\title{
THE INDUSTRIAL CONDITION OF THE NEGRO IN NEW YORK CITY
}

\author{
By William L. BulkLey,
}

Principal Public School No. 8o, Borough of Manhattan, New York.

During the nineteenth century the Afro-American population of New York State increased more than 300 per cent., or from 31,320 to 99,232 . The greatest percentage of increase in any decade was from 1890 to 1900 , or 70,092 to 99,392 .

New York City has received the largest part of this increase, the population almost doubling in the twenty years from 1880 to 1900 , or 36,134 to 65,984 . In 1890 the Afro-American population of New York City was 42,816; to 1900 there was a gain of 23,000 . In the whole State during the same period there was a gain of 29,000.

New York City now has a larger Negro population than any other Northern city, and stands fourth in the list of all cities of the United States.

This great influx is due both to the universal tendency to drift to urban centres (the larger the city the more attractive) and also to the intolerable civil, social, educational, and political conditions existing in various parts of the South.

But we are not to discuss the cause of their flocking to the city, but rather to discover what they are capable of, what they are now doing, and what hope is before them. Therefore,

( 1 ) Is the Afro-American possessed of the necessary qualifications to hold his own in the strenuous industrial and economic conflicts of a city like New York?

(2) Are his opportunities for employment conducive to the development of the best of which he is capable?

(3) What kinds of employment are open to him?

(4) Is prejudice increasing or diminishing? Is there reason to hope that he will find a satisfactory place among other craftsmen in the various lines of industrial endeavor?

(590) 
(I) With regard to the first question, it would be needless to take time to touch upon it, if one would only remember that for two centuries almost all the labor of the South, both skilled and unskilled, was by the man of African lineage. He was not only the butcher that slaughtered the cattle, but also the tanner that prepared the hide, and the shoemaker that put it into shape. $\mathrm{He}$ was the laborer who felled the tree as well as he who sawed it into boards, and he who built the house. He was the brickyard hand who dug the clay and burned the brick; he was also the workman who put the finished product into buildings. Though his field is being now encroached upon by the native white man and the foreigner, he is still the ubiquitous artisan of the South. He comes to New York and other cities with this same skill of hand, ready and anxious to continue his trade. Where he has found employment he has given satisfaction.

(2) Such being the case, does he readily find employment? Or, rather, does he find employment as readily as the other immigrants to the city? Does he, a native of the United States, have an equal chance with the unnaturalized European immigrant, or does he suffer a disadvantage? Unfortunately and regretfully the last is the case. While there are many unions that are, in their constitution, open to all men, there are others which bar the doors tight against any man with an admixture of African blood. There is, further, a conviction that even the supposedly open unions do not always give the black brother a cordial welcome. As a result of these conditions there were reported in the last census only 4,4I9 men and I,40I women engaged in manufacturing and mechanical pursuits out of a total population of 99,232 in the State. It is safe to assume that many of these so rated were only irregularly employed, working at their trades as odd jobs. An investigation of the rosters of trades unions would in all probability show only a minority of them as members.

(3) What, then, are the vocations in which the majority of Afro-Americans are to be found? The census of Igoo shows that there were in New York State 57,000 at work over ten years of age. Deducting from the aggregate those in professional service, such as physicians, dentists, teachers, clergymen, actors, musicians, etc, I,342 ; trade and transportation, I,O2I ; manufacturing and mechani- 
cal pursuits, 5,820, we have left about 49,000 in service more or less menial. Between the 57,000 reported as at work and the 99,000 in population we have the difference of 42,000 to be accounted for as follows :

Under school age $\ldots \ldots \ldots \ldots \ldots \ldots \ldots \ldots \ldots \ldots, 7,000$

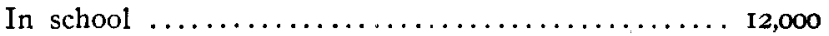

Mothers in charge of own homes .............. 10,000

We would still have 13,000 to account for as in hospitals, institutions, unable to work, or idle.

Most of the skilled laborers among Afro-Americans in New York have migrated there after learning their trades in the South or the West Indies-fathers of families many of them; in some cases bringing their families with them; in others leaving their families till employment is secured. As deeply concerned as one may be about their welfare, of no less importance is the problem, What shall be done with and for the boys and girls that are growing up in our city?

Some one has remarked that, if a boy in the city of New York wants to learn a trade he must commit a crime, meaning by this that he would be sent to one of the reformatories where manual training forms an important part of the school curriculum. It may not be so bad as this, but this much is certain, the boy, whether white or black, finds it no easy task to learn a trade. For the white boy, however, this difficulty is counterbalanced, at least to some extent, by the many opportunities offered in business. The colored boy, on the other hand, runs sheer up against a stone wall here. As an illustration of the difficulties that confront a colored boy I may cite one case. I received a communication the other day from an electric company (possibly all other male principals received the same) stating that they could use some bright, clean, industrious boys in their business, starting them at so much a week and aiding them to learn the business. I suspected that they did not comprehend colored boys under the generic term "boys," but thought to try. So I wrote asking if they would give employment to a colored boy who could answer to the qualifications stated. The next mail brought the expected reply that no colored boy, however promising, was wanted. $I$ heaved a sigh and went on.

The saddest thing that faces me in my work is the small opportunity for a colored boy or girl to find proper employment. A boy 
comes to my office and asks for his working papers. He may be well up in the school, possibly with graduation only a few months off. I question him somewhat as follows: "Well, my boy, you want to go to work, do you?" "What are you going to do?" "I am going to be a doorboy, sir." "Well, you will get $\$ 2.50$ or $\$ 3$ a week, but after a while that will not be enough ; what then?" After a moment's pause he will reply: "I should like to be an office boy." "Well, what next?" A moment's silence, and, "I should try to get a position as bell-boy." "Well, then, what next?" A rather contemplative mood, and then, "I should like to climb to the position of head bell-boy." He has now arrived at the top; farther than this he sees no hope. He must face the bald fact that he must enter business as a boy and wind up as a boy.

A bright boy came to me one day for his working papers. I was sorry to see him want to leave school, but he had no father, and his poor mother had the hardest sort of job to earn enough over the wash-tub to pay the rent for their two rooms and to buy their meager food and clothing. The boy earned what little he could by odd jobs in the afternoon, Saturdays and holidays. Still, I felt that if I could get him to stay till he could finish he might chance to find something better; but that would mean at least three years more of school. In reply to my urgent request that he try to battle through, with sad face he said: "I am old enough now to help mother; she needs me. And, again, there is nothing better for a colored boy to do if he finishes the course." The reply pierced my heart like a white-hot bolt. I shall remember that scene till my dying day. All the monster evils of prejudice passed before me in procession like the hideous creatures of an Inferno, and I thought of the millions of hopes that have been blighted, the myriads of human possibilities that have been crushed, the intellects that have been stunted, the moral lives that have been gnarled and twisted, all because the iron heel of this base, hell-born caste is upon the neck of every boy, of every girl who chanced to be born black.

(4) But should he despair? Is there any rift in the cloud? Can one catch here and there a ray of light, of hope, of encouragement through the oppressive pall?

Let me cite a few instances why we should not despair in New York City. 
(a) The liberal educational system.

(b) The numerous stalwart friends of humanity in the pulpit, at the bar, in the press, on the rostrum, in business, and in the trades.

(c) The influx of foreigners.

(d) The spirit of our government.

(e) The growth of socialism.

(f) The determination of the people to rise.

(a) Our educational system. There is no such a thing as a caste public school in the whole Empire State. The two men who, as Governors of our State, did most to kill this vicious distinction in our public schools are the two men who deserve to rank through all time among our most distinguished Presidents-Grover Cleveland and Theodore Roosevelt. Educate the children of our land together; the result is a better understanding of each other, a kinder feeling one for the other; a diminishing distrust ; and an increasing mutual respect. Common interests in childhood are the seeds that develop into common interests in manhood. This system of mixed schools is to me one of the most hopeful means of a satisfactory solution of our civil and industrial problems. Further, through the liberalmindedness of our excellent city superintendent and his aides and because of the fairness of our Board of Education and the Board of Examiners there are possibly more colored teachers in our public schools than in any city north of the Mason and Dixon line. They stand entirely on their merit, and are winning the respect and confidence of all who know them.

(b) A powerful force for present and future good are the many men and women in the higher professions who stand for equality of opportunity, liberty, justice. They are legion. They are the sinew, the brain, the blood, the very life of every movement for the betterment of our people in this city. They are too numerous to mention. To name even one would be unfair to the thousands of equal zeal and goodness. No false note there; their ring is always clear and true and forceful.

(c) The cosmopolitan nature of our population. The hundreds of thousands of Europeans who crowd our city have brought nothing against the black man. All that they know and feel has been learned and acquired here. It is skin-deep only; not born in them, soaked through the bone and marrow. 
(d) The spirit of our constitution is all right. Whatever is wrong is but the flapping of the sail; the old ship is secure. The time must come when all men under the stars and stripes will enjoy the right to work as well as the right to life, liberty, and the pursuit of happiness !

(e) The growth of socialism, as represented by such men as Eugene V. Debs, promises equal opportunity to all men.

(f) Lastly, the determination of the people to rise is itself the highest and best encouragement. Even with all the keen opposition that a small business man feels, one finds scores, yes hundreds of small enterprises, mercantile and industrial, conducted by colored men and women in the city. They are increasing with normal rapidity.

A most encouraging evidence of the eagerness to know how to do something well, to be prepared for some sphere of industrial usefulness was the attendance this winter at our evening school for adults. We had expected to register possibly 200 people in the common branches (the three R's) and the industrial classes; but we registered $I, 500$ people, of whom about $I, 300$ were colored. The enthusiasm in the work, the faithfulness in attendance, the excellence of results, so pleased the Board of Education that they are planning to enlarge the plant next year.

To show the spirit that filled this school, permit me to draw a picture as I drew it some months ago in the press of New York:

\section{Future of Colored Race.}

To the Editor of the New York Times:

While Dixon's "Clansman" is being played next door, Evening School No. 80, in which 1,000 colored men and women have registered, is industriously attending to business.

Within thirty feet of my office, where I now write this, the curtain is possibly being raised at this moment in an effort to portray the negro race in the worst possible colors; within this building hundreds of the maligned race are at the same moment quietly but earnestly working at their books or in the trades.

So far as I can note, not one of them cares a straw what slanders any marplot may heap upon them; happy, hopeful, busy each and all.

What a refutation to all pessimism would it be if the audience in the theatre would take a recess for a few moments and go through our classrooms! Suppose they could see these men and women, up to sixty-seven years of age, present in full force this stormy night, hungry for knowledge, 
determined to learn some trade that will make them worth more to the community - what an object lesson it would be!

Not a room in the building is vacant. Even seats for baby pupils and kindergarten tables are occupied. Neither cold nor heat, snow nor moonshine, with all their attendant drawbacks or attractions, can keep these pupils away.

In the theatre the audience is looking at the past; these people are looking into the future. To the one crowd despair; to the other hope.

What may be the thoughts of the people who are witnessing the play I do not know, but of this much I am sure-there are not 700 happier people in any building in New York than those who are busy here to-night.

New York, January 8, I906.

Willia m L. Bulkley, Principal.

To be sure, we have our full share of worthless men and women who are a disgrace to humankind. May their tribe diminish! But, in my moments of quiet contemplation, I wonder not that there are so many Afro-Americans that are good for nothing, but that there are so few. It takes tremendous courage and determination to rise to the plane of respectability beneath such a Cyclopean weight of prejudice. A little charity towards the weak brother and sister cannot surely be too much to ask.

In closing, let me appeal for the establishment of trade schools in the cities of the North to do work similar to that done in our industrial schools in the South. And, then, let this be held out before every boy and girl of all the races as one of the fundamentals of our constitution-the right to work; opportunity to work; encouragement to work in any sphere in which one may be useful. 